\title{
Anilocra montti sp. n. (Isopoda, Cymothoidae) a parasite of caged salmon and trout in Chile ${ }^{1}$
}

\author{
Vernon E. Thatcher ${ }^{2}$ \\ Carlos Lobos Blumenfeldt ${ }^{3}$
}

\begin{abstract}
Anilocra montti sp. n. (Isopoda, Cymothoidae) is described from the mouths and branchial chambers of caged salmon and trout from Puerto Montt, Chile. The description is based on a detailed study of 30 male specimens. No females were found, indicating that salminoids are not the normal hosts of the parasite. The new species differs from others in the genus by having carinae on pereopods 4-7, a pleon that is abruptly narrower than the pereon, second pleopods without appendices masculina, a pleotelson that is wider than long and uropods with subequal rami.

KEY WORDS. Isopod, cymothoid, fish parasite, Chile, South America
\end{abstract}

Cymothoid isopods as parasites of marine fishes are found in most parts of the world but are more numerous in warm coastal waters of tropical and subtropical regions.

TRILLES (1991) listed 39 species for the genus Anilocra worldwide. WILLIAMS \& WILLIAMS (1981) described nine new species of Anilocra from the Caribbean Sea, one of which occurs as far south as Patagonia and the Strait of Magellan.

BRUSCA (1981) reported only two species of the genus from the Eastern Pacific Ocean, one of which might occur along the South American coast. ROKITSKY (1984) described Anilocra huacho from coastal waters of Peru. The present paper describes a new species of this genus from cultured salmonoid fishes of Southern Chile.

\section{MATERIAL AND METHODS}

Cymothoids were removed from the mouths or gill chambers of their hosts and preserved in $70 \%$ alcohol. Appendages were dissected from the isopods and cleared in pure phenol for study in temporary mounts. Permanent preparations were made by means of the phenol-balsam method described in THATCHER (1991). Photographs of the mouthparts were made with a digital camera and a standard light microscope. Drawings were made with the aid of a camera lucida. Measurements are in micrometers $(\mu \mathrm{m})$ unless designated as millimeters $(\mathrm{mm})$.

1) Contribution number 1298 of the Departamento de Zoologia, Universidade Federal do Paraná.

2) Departamento de Zoologia, Universidade Federal do Paraná. Caixa Postal 19020, 81531-990 Curitiba, Paraná, Brasil. Research Fellow of the CNPq.

3) Aquatic Animal Health, Puerto Montt, Chile. 

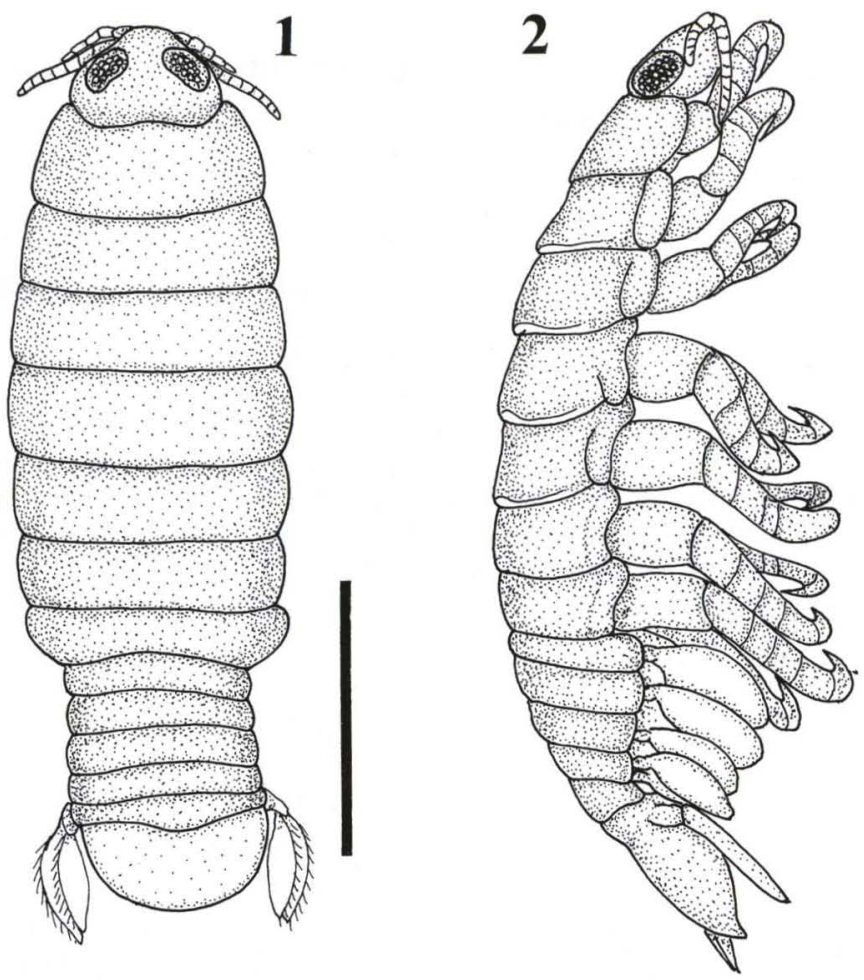

Figs 1-2. Anilocra montti sp. n., male. (1) Dorsal; (2) lateral. Scale $=5,0 \mathrm{~mm}$.

\section{Anilocra Leach, 1818}

Generic diagnosis (emended). With the characters of the family Cymothoidae. Cephalon with triangular apex which is folded ventrally between bases of antennae; posterior margin more or less trilobed; not immersed in first pereonite. Coxal plates small. Pereopods 4-7 with or without carinae. Pleopods 3-5 often pleated; pleopod 2 may lack appendix masculina. Uropods usually project posteriorly beyond margin of pleotelson. Parasites of skin of marine fishes (frequently found near eye) and sometimes the branchial chambers.

\section{Anilocra montti sp. $\mathbf{n}$.}

Figs 1-25

Hosts. Onchorhynchus mykiss (Walbaum, 1792) - Rainbow trout; Onchorhynchus kisutch (Walbaum, 1792) - Coho salmon.

Sites. Over tongue and in the branchial chambers.

Locality. Near Puerto Montt, Chile.

Intensity. 1-3 individuals per infected fish. 

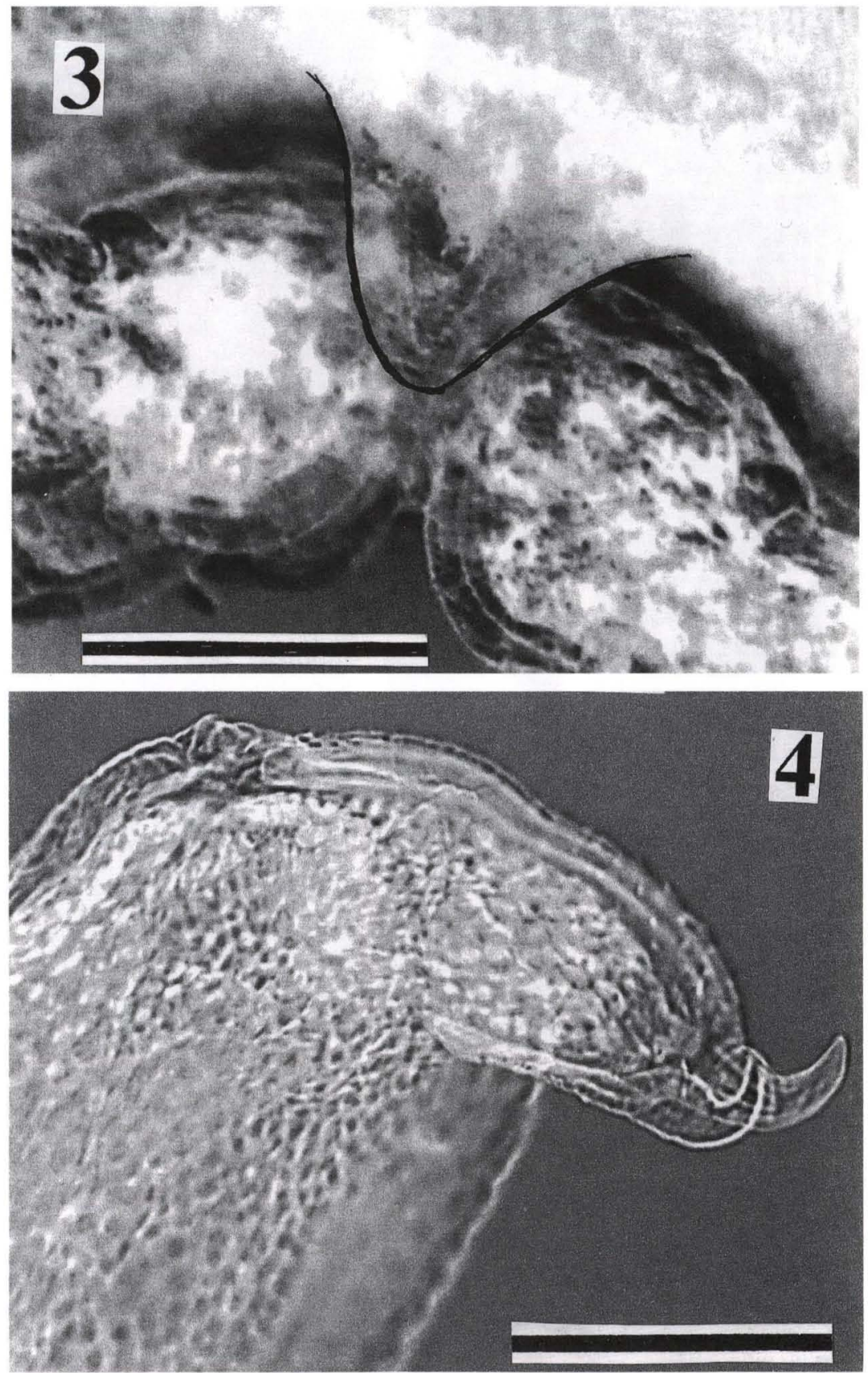

Figs 3-4. Anilocra monttisp. n., male. (3) Anterior margin of cephalon folded between antennal bases, scale $=500 \mu \mathrm{m}$; (4) maxillipedal palp, scale $=100 \mu \mathrm{m}$. 

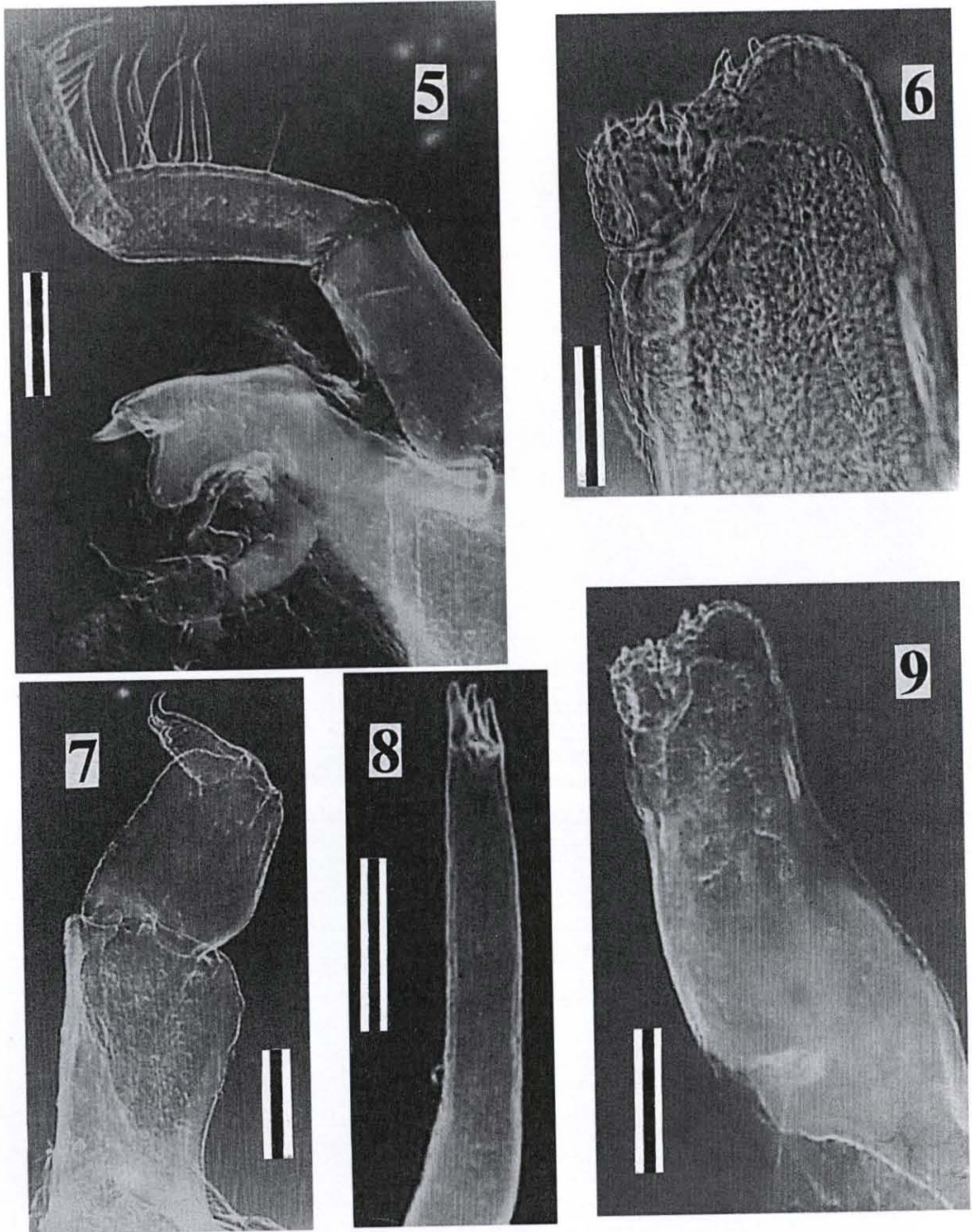

Figs 5-9. Anilocra montti sp. n., male. (5) Mandible and palp; (6) tip of maxilla; (7) maxilliped; (8) maxillule; (9) maxilla. Scales 5,7 and $9=200 \mu \mathrm{m}, 6$ and $8=100 \mu \mathrm{m}$.

Prevalence. 3-4\% in Autumn.

Holotype male and four male paratypes deposited in the Crustacean Collection of the Instituto Nacional de Pesquisas da Amazônia (INPA), Manaus, Amazonas, Brazil.

Etymology. The species name is based on the type locality.

Description (based on studies of 14 male specimens). Measurements given in table I. General body coloration similar to burnt umber (color 22 in SMITHE 1975).

Body about 3.4 times longer than wide (Fig. 1). 

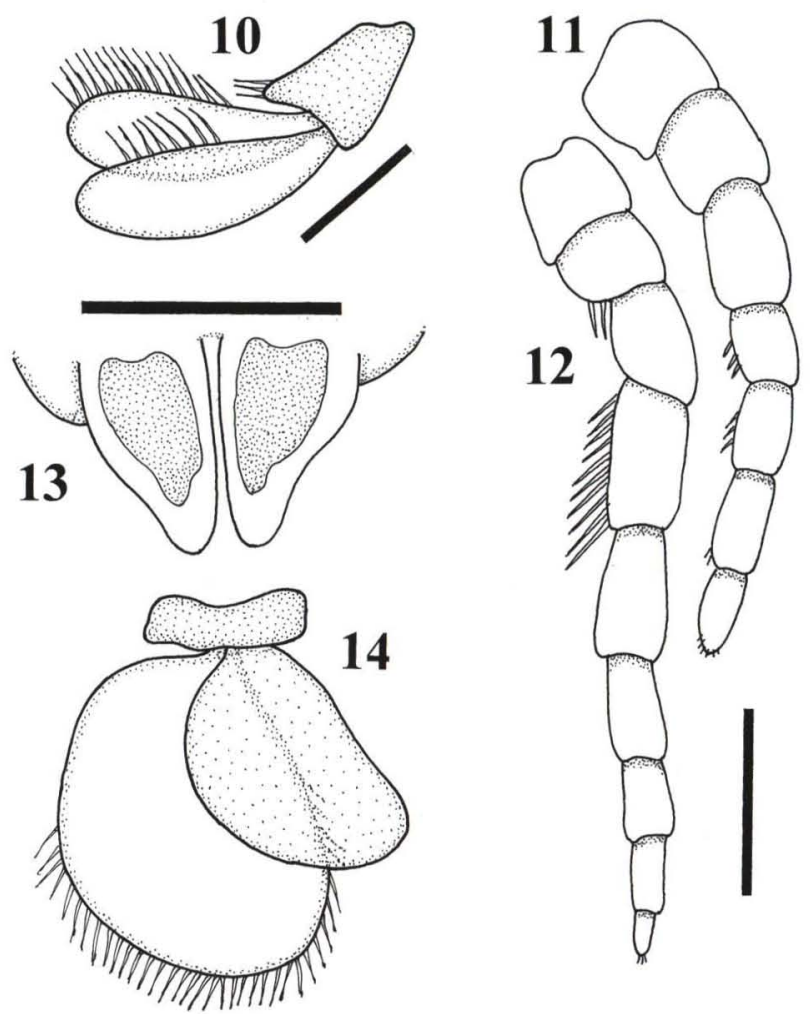

Figs 10-14. Anilocra monttisp. n., male. (10) Uropod; (11) antennule; (12) antenna; (13) penis; (14) pleopod 5. Scales 10 and $13=500 \mu \mathrm{m}, 11-12=500 \mu \mathrm{m}, 14=$ same as 22-25.

Table I. Measurements in millimeters of ten males of Anilocra montti sp. $\mathbf{n}$.

\begin{tabular}{cccc}
\hline Length & Width & Pleon L/W & Pleotelson L/W \\
\hline 12 & 3.5 & $4.0 \times 2.0$ & $1.5 \times 2.5$ \\
13 & 3.8 & $4.8 \times 2.0$ & $1.5 \times 3.0$ \\
13 & 4.0 & $4.5 \times 2.5$ & $1.5 \times 3.0$ \\
13 & 4.0 & $5.0 \times 3.0$ & $1.5 \times 3.0$ \\
13.5 & 4.0 & $5.0 \times 2.5$ & $1.5 \times 3.0$ \\
14 & 4.0 & $5.0 \times 3.5$ & $2.0 \times 4.0$ \\
16 & 4.0 & $5.5 \times 3.0$ & $2.5 \times 3.5$ \\
17 & 5.0 & $5.5 \times 4.0$ & $3.0 \times 4.5$ \\
17 & 5.5 & $6.0 \times 4.0$ & $3.0 \times 4.5$ \\
17 & 5.0 & $5.5 \times 3.5$ & $2.5 \times 4.0$ \\
\hline
\end{tabular}

Cephalon not immersed in pereonite 1 (Figs 1-2); trisinuate posteriorly; rostrum triangular, folded between bases of antennules (Fig. 3). Antennules of seven articles, shorter than antennae; with few setae along posterior margin of last four articles (Fig. 11). Antennae of nine articles; few setae on second article and numerous marginal setae on article 4; with 3-4 small setae terminally (Fig. 12). 


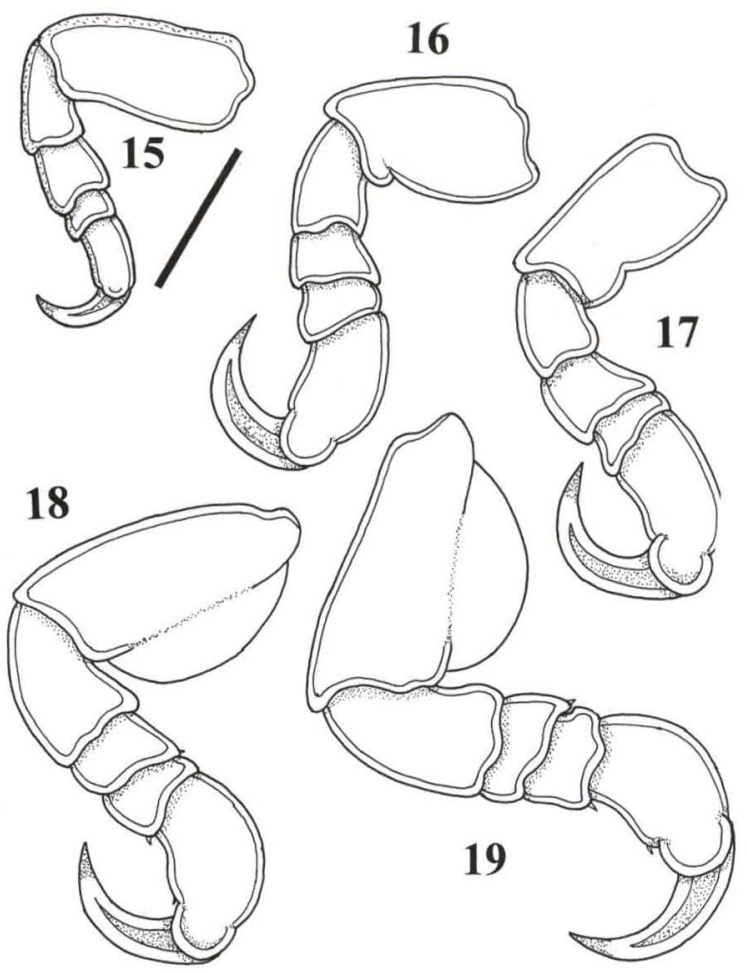

Figs 15-19. Anilocra montti sp. n., male. (15) Pereopod 1; (16) pereopod 2; (17) pereopod 3; (18) pereopod 4; (19) pereopod 5 . Scale $=1,0 \mathrm{~mm}$.

Mouthparts. Mandible (Fig. 5) with prominent incisor and molar process; palp long, estends beyond mandible, with numerous setae on last two segments. Maxillule (Fig. 8) with four terminal recurved spines. Maxilla (Figs 6,9) bilobed, with few terminal spines and spinules. Maxilliped (Figs 4,7) with two recurved spines on palp.

Pereon with sides nearly parallel, widest at pereonite 4; pereonite 1 twice as long as 7, others subequal; lobes of penis well developed, separated (Fig. 13). Pereopods (Figs 15-21) unequal in length, $1^{\text {st }}$ smallest, increase gradually in size to $7^{\text {th }}$ which is largest. High carinae on bases of pereopods 4-7. All pereopods provided with strong hooked dactyls.

Pleon (Fig. 1) abruptly narrower than pereon; sides nearly parallel; represents $29-38 \%$ of body length; not immersed in pereonite 7. Pleopods (Figs 14, 22-25) simple, biramous, endopod smaller than exopod, lacking appendix masculina; with numerous marginal setae.

Pleotelson (Fig. 1) wider than long. Uropods (Fig. 10) with subequal rami; project posterior to margin of pleotelson.

Discussion. Williams \& Williams (1981) gave a detailed review of the history of the New World species of Anilocra. They considered Anilocra laticauda Milne Edwards, 1840, to be a nomen dubium since the original description and 

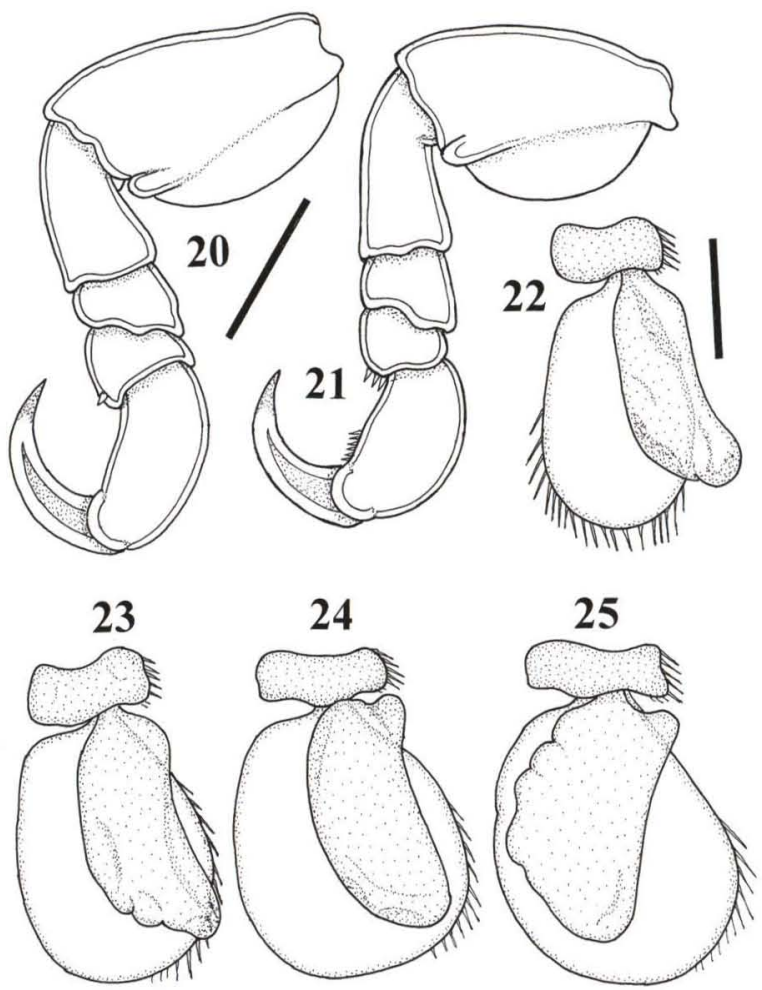

Figs 20-25. Anilocra montti sp. n., male. (20) Pereopod 6; (21) pereopod 7; (22) pleopod 1; (23) pleopod 2; (24) pleopod 3; (25) pleopod 4. Scales: $20-21=15-19,22-25=1.0 \mathrm{~mm}$.

subsequent redescriptions had been based on a mixture of distinct species. They described nine new species of the genus some of which had been previously called A. laticauda by others.

The new species herein described plainly belongs to the genus Anilocra by virtue of the fact that the frons is bent downward between the bases of the antennules. Anilocra montti sp. $\mathbf{n}$. differs from the other known species in having carinae on pereopods 4-7, a pleon that is abruptly narrower than the pereon, a pleotelson that is wider than long, second pleopods without appendices masculina and uropods with subequal rami.

\section{REFERENCES}

BRUSCA, R.C. 1981. A monograph on the Isopoda Cymothoidae (Crustacea) of the eastern Pacific. Zool. Jour. Linnean Soc. 73 (2): 117-199.

RoкITSKI, J. 1984. A new isopod, Anilocra huacho sp. n. of the family Cymothoidae from coastal waters of Peru. Parazitologya, Saint Petersburg, 18 (3): 242-244.

Smithe, F.B. 1975. Naturalist's color guide and supplement. New York, Amer. Mus. Nat. His., 229p. Thatcher, V.E. 1991. Amazon fish parasites. Amazoniana, Ploen, 11 (3/4): 263-571. 
Trilles, J.P. 1991. Les Cymothoidae (Crustacea, Isopoda) du monde. Studia Marina, Kotor, 21/22: 5-288.

Williams, L.B. \& E.H. Williams JR. 1981. Nine new species of Anilocra (Crustacea: Isopoda:

Cymothoidae) external parasites of West Indian coral reef fishes. Proc. Biol. Soc. Wash. 94: 1005-1047.

Recebido em 23.XI.2000; aceito em 28.VI.2001. 